\title{
Significance of Surface Lineaments for Gas and Oil Exploration in Part of Sabatayn Basin-Yemen
}

\author{
Arafat Mohammed (Corresponding author), Palanivel K \& C.J.Kumanan \\ Centre for Remote Sensing, Bharathidasan University \\ Khajamalai Campus, Tiruchirappalli-23, Tamil Nadu, India \\ Tel: 91-962-673-6224 E-mail: arafatmohmmed@gmail.com \\ SM.Ramasamy \\ Gandhigram Rural University, Dindigul, Tamil Nadu, India
}

\begin{abstract}
Sabatayn basin is one of the two mature basins producing oil and gas in Yemen. Due to the recent decline in oil production, the exploration activities have been extensively concentrated mainly on these two basins (Sabatayn and Sayun-Masilah). So, this present study has been conducted to evaluate the exploration potential of the remaining trap areas within these mature basins. Fracture basement of reservoir becomes very attractive exploration target in Yemen recently, after the recent discoveries of basement fracture oil fields. As the evaluation of basement traps needs time and fund, to reduce the same, this research study uses a new technique which was devised with the help of Geoinformatics by analyzing the surface and subsurface lineaments effectively. In this study, a satellite image Enhanced Thematic Mapper (ETM+7) based analysis was conducted for extracting surface lineaments, and for the subsurface lineaments, the basement lineaments were extracted from seismic, magnetic and gravity data. An orientation analysis of these surface and subsurface linear features was performed to detect the basic structural grains of the study area. The correlation between these structural grains and subsurface oil and gas traps was performed to understand the connectivity to the reservoirs. This paper discusses in detail about the same and the importance of using surface and subsurface lineament analysis for delineating hydrocarbon reservoirs in the study area.
\end{abstract}

Keywords: Lineament extraction, Analysis, Orientation, Traced oil trap, Sabatayn Basin

\section{Introduction}

The geological evolution of Yemen was driven by the plate motions that broke Pangaea apart during Mesozoic and formed the Gulf of Aden, Red Sea and the Arabian Peninsula during Cenozoic. The stratigraphic and regional geology of Yemen was established by the detailed works of Beydoun(1964), Powers et al. (1966), Beydoun and Greenwood (1968), Hughes and Beydoun (1992), Paul(1990), Schlumberger (1992), and Beydoun et al. (1993). Hydrocarbon exploration activity became extensive after 1990 and provided considerable amount of subsurface data, which revised the synthesis of basin evolution in Yemen, through the research works of Redfern and Jones (1995), Ellis et al. (1996) and Beydoun et al. (1996). The concepts and new methodologies of petroleum exploration for Yemen country were summarized by Csato et al. (2001). The Sabatayn Basin was identified as a NW-SE trending rift basin comprising a series of asymmetric half grabens (Csato et al., 2001), which had been thought to have inherited the trend of Precambrian Najd Strike-slip Faults. Rifting was initiated in the Late Jurassic (Kimmeridgian to Tithonian) and was followed by thermally driven (post-rift) subsidence and a period of uplift and erosion during the Early Cretaceous. A second rift phase (Hauterivian to Parremian) was associated with local reactivation of some graben-bounded fault systems. A large number of intra-basinal highs were active and the sedimentation was controlled by these highs throughout the Late Jurassic and Cretaceous. The Mesozoic rifting and sedimentary basin evolution is well discussed (Redfern and Jones, 1995; Beydoun et al., 1996), while the complex, polyphase tectonics in the Tertiary (Ellis et al., 1996) is much less understood. At the end of the syn-rift phase, the Sabatayn basin became isolated from the sea maintaining a periodically opened marine passage, which supplied saline water into the basin. The geographic separation and warm climate gave rise to massive evaporation. The salt deposited in Sabatayn basin produced various halokinetic features during the Cretaceous and Cenozoic time. During this evolutionary period of this Sabatayn basin, several types of tectonic faults and lineaments were developed and acted as conduits for the migration of hydrocarbons. 
The major aim of this research study is to understand the significance and the relationship between the surface and subsurface lineaments for oil and gas exploration in part of Sabatayn Basin. The study has been conducted in three Blocks within the basin; Block 4 (producing oil) and Blocks $2 \& 3$ (under exploration). Existing studies on surface and subsurface lineaments in the study area have been reviewed. Information on surface and subsurface lineaments interpreted from satellite images, gravity and magnetic surveys or through surface monoclinal analysis have been collected, digitized, and analyzed. Reports of seismic surveys carried out within the area have also been used for basement lineament analysis. An orientation analysis was performed, to bring out the correlation between surface and subsurface lineaments, as well as between surface lineaments and subsurface oil and gas traps. Finally, the significance of the said analyses for delineating additional traps in the Sabatayn basin was assessed.

\section{Study Area}

The study area is located in the central to the south eastern part of Sabatayn basin, known as Shabwah-Hajar Basin, bounded between the upper and lower coordinates, $15^{\circ} 20^{\prime} 00^{\prime \prime} \mathrm{N}-46^{\circ} 30^{\prime} 00^{\prime \prime} \mathrm{E}$ and $14^{\circ} 40^{\prime} 00^{\prime \prime} \mathrm{N}-47^{\circ}$ $40^{\prime} 00^{\prime \prime} \mathrm{E}$, respectively (Figure-1). The study area is characterized by varied terrain consisting of relatively low relief desert in the West, (underlain by Cretaceous Sandstone) and prominent cliffs which give rise to an extensive Central and Eastern plateau (capped by the Tertiary Carbonate units) which has been deeply incised by several sets of drainages.

\section{Method of the study}

The method of the study consists of four main steps. In the first step, digital GIS database has been generated on different thematic maps such as surface lineaments, drainages and subsurface lineaments using satellite, subsurface Basement, Gravity and Magnetic data. The second, third and fourth steps involves GIS integration of several lineaments extracted using the said different data sets, orientation analysis of linear features to see the directional relationships and finally to bring out significance of surface lineaments for oil and gas exploration in the area of study accordingly. The (Figure.2) shows a diagram expressing the method of study in brief.

\subsection{Surface Lineaments extraction}

The satellite images due to its many capabilities such as the synoptic aerial coverage, multi spectral captivity of data, temporal resolution, etc., they produce better information than conventional aerial photographs (Lillesand and Kiefer, 1999), so the same has been selected for the task of extracting surface lineaments. Radiometric correction is applied to images to remove noise present in the image. A $3 * 3$ Median filter is applied to all bands of Landsat Enhanced Thematic Mapper ETM+7 satellite images and maintain the output values which are not affected by the actual values of outlier cells within the filter window. The median filter is particularly good for removing isolated random noise. With the help of image interpretation keys and elements, lineaments are interpreted for the entire study area using standard FCC (False Color Composite). As the digital image enhancement techniques can contribute significantly in extracting lineaments, the same have been attempted using the software ENVI 4.3. Among the variety of image enhancement techniques, the filtering operations (Suzan and Topark, 1998, Chang et al. 1998, Mah et al. 1995), principal component analysis(PCA) (Qari, 1991; Nama, 2004), and spectral ratioing (Arlegui and Soriano,1998) are the most commonly used ones and the same have been applied in the study. The final lineament map has been generated by integrating all the lineaments interpreted using raw, FCC and enhanced satellite data and GIS layer has been generated (Figure.3).

\subsection{Basement faults, Gravity and Magnetic Lineaments}

Various reports and papers have been published on the analysis of subsurface lineaments interpreted from Gravity, Magnetic and Basement structures. Johnsgard (1983), and Berendsen et al. (1983) analyzed the gravity, magnetic data and the basement fault system in Kansas and observed that the alignment of oil and gas field reservoirs along major basement fault trends. Gravity data and Seismic profiles have been used by Yahya A Al Fastawi and Paul M van Dijk (1990) for the purpose of interpreting the basement lineaments and correlated it with the surface linearities interpreted from Landsat TM and Radar images and they concluded that there was a strong relation between surface and subsurface lineament related to the oil and gas fields.

In this present study, basement fault system map of the area was digitized from the reports of oil companies after the interpretations of seismic profiles and sections and the GIS layers thus developed has been named as Seismic Fault System. Gravity and Magnetic lineaments were interpreted from the breaks visualized by creating 3D (DEM) model resulted from the said isolines using ArcMap 9.3 software (Figure.4) shows A,B)Magnetic and Gravity contour values superimposed over Landsat satellite image of the study area, C,D)Magnetic and Gravity 3D DEM models. These techniques are widely used in the recent years for the analysis of lineaments. (Figure. 
5(A, B, and C, D)) shows the lineament maps derived from such surface, magnetic, gravity and basement data respectively.

\subsection{Orientation analysis of Lineament}

Linear feature orientation is considered as one of the most important characteristics as far as petroliferous locales are concerned. In this present study, the lineaments, fractures and their traces seen on the surface, gravity, magnetic lineaments and basement faults are analyzed for their orientations. Rose diagrams are one of the most informative ways of representing orientation data. Rose diagrams for all the linear features acquired in the study area were shown in (Figure.6). They were generated based on their trends and frequency. However one can see from these rose diagrams that the surface linear features in the study area have four preferred orientations: Northwest-Southeast, Northeast-Southwest, North-South, and East-West. Majority of the surface linear features in the area are oriented in two directions, i.e., one along Northwest-Southeast and the other along Northeast-Southwest. Whereas, those surface linear features oriented in North-South and/or East-West are less prevalent (Figure. 6D).

The rose diagram of basement fault system in the area shows that they are preferably oriented in Northwest-Southeast direction (Figure. 6A). The gravity lineaments appear primarily in four sets: two major sets are oriented in Northwest-Southeast and East-West, and the other two minor sets are oriented in Northeast-Southwest and North-South. Magnetic lineaments appear primarily in three sets: one major set oriented Northwest-Southeast, and two minor sets oriented in Northeast-Southwest and East-West (Figure. 6B). A comparison of the surface and subsurface linear features indicates that the basement faults are very much congruent in orientation with the gravity, magnetic and surface lineaments in the region of study. The Precambrian basement fault system consists of a major set trending in Northwest-Southeast direction. These faults later were reactivated and thus acted as conduits for the upward propagation of hydrocarbon all the way to the surface, as reflected by the geophysical anomalies and the surface lineaments. During the process of reactivation and propagation, additional sets of faults and fractures were developed due to local structural and tectonic disturbances and their complications. The connectivity from the basement fault systems upward till the surface provides a mechanism for hydrocarbon migration and entrapment.

\subsection{Significance of surface lineaments for oil and gas exploration}

In the study area, active oil seeps were located and marked besides the locations of oil and gas fields (Figure. 1). Three such oil and gas fields are located in the Shabwah sector of Sabatayn basin, and those fields are producing from Jurassic mature basin. However as a result, the surface linear features have been used to search for additional reserves in mature oil and gas fields (Herman et al. 1986; Perry and Lee 1986; Swanson and Shannon 1990, and Guo and Carroll 1995). From the overlay of surface and subsurface lineaments on oil and gas fields and active seeps locations prepared using ArcGIS (Figure.7), one can observe that the locations of oil fields are bounded by major surface linear features from both sides shaping the boundary of sub graben and sub basins in the area. The surface lineaments are in parallelism with the subsurface basement faults. This case can be very well noticed in East Ayad oil field. If we look into the locations of active oil seeps, they are exactly located over the surface lineaments. Thus, the surface lineaments were used as a guide to structural contouring, facies mapping, and delineation of areas of fracture-enhanced permeability. Also, their trends were used directly to conduct seismic programs and to select deeper exploration candidates in the area.

Based on the above observations about the significance of using surface lineaments for oil and gas exploration in parts of Sabatayn basin, as well as the general consistency in orientation between the oil and gas fields and surface and subsurface linear features in the study area, it is possible to conclude that the potential new oil and gas reservoirs in the remaining parts of the basin, if they exist, will be likely associated with the surface lineaments. Therefore, surface lineaments should be employed as a cost effective tool for delineating preliminary locations for more sophisticated and more expensive geophysical and/or geochemical surveys in the Sabatayn basin.

\section{Results and Discussions}

Using the raw, FCC and digitally enhanced Landsat ETM satellite images of the study area, surface lineaments have been interpreted and integrated GIS layer has been generated using AcrGIS. The gravity and magnetic lineaments have been extracted from visualized breaks of converted 3D maps of both gravity and magnetic contour maps and the same were digitized and GIS layers have been generated. Another GIS layer on Basement faults system was prepared as a result of seismic interpretations of top basement horizon of the area. An orientation analysis was performed and the significance of using these surface linear features for inferring potential oil and gas traps in the area was assessed. 
The surface linear features in the study area have four preferred orientations: Northwest-Southeast, Northeast-Southwest, North-South, and East-West. A majority of the surface linear features in the area are oriented in northwest-southeast and northeast-southwest. On the contrary, those surface linear features oriented in north-south and/or east-west is less prevalent.

The gravity lineaments appear primarily in four sets of directions: two major sets oriented in Northwest-Southeast and East-West, and the two minor sets oriented along Northeast-Southwest and North-South.

Magnetic lineaments appear primarily in three sets of directions: one major set is oriented in Northwest-Southeast, and the other two minor sets are oriented in Northeast-Southwest and East-West directions.

The basement fault system in the study area is primarily oriented in one direction, i.e., Northwest-Southeast.

The general consistency in orientations among the Precambrian basement faults, the lineaments interpreted from gravity and magnetic data, and the surface linear features indicates that the systematic fault system at basement in the area probably have been reactivated many times and thus have connectivity upward all the way to the surface. Therefore, they may have acted as the propagators and conduits for the hydrocarbons in the study area.

\section{Conclusion}

Through the association between surface linear features and subsurface oil and gas traps which was observed in East Ayad field and also with some active oil seeps in the area, it is possible to assume that this relationship also exists in other parts of the basin. Therefore, it is concluded with a strong recommendation that the surface lineament and fracture analysis should be employed as a cost effective tool for hydrocarbon exploration in Sabatayn basin.

\section{References}

Al Fastawi, Y. A. and Van Dijk, P.M. (1990). Lineament and Geomorphic Analysis of Remote Sensing Data As an Aid to Hydrocarbon Exploration, Sirt Basin, Libya. ITC Journal: Bulletin de l'ITC, (1990)2, PP. 137-144.

Arlegui, L.E., Soriano, M.A. (1998). Characterizing Lineaments from Satellite Images and field Studies in the Central Ebro Basin (NE Spain). International Journal of Remote Sensing, Vol. 19, No.16, 3169-3185.

Berendsen, P., F. W. Wilson, H. L. Yarger, and D. W. Steeples. (1983). New Data on Major Basement Fractures in the Tectonics Development of Eastern Kansas. Proceedings of the 3rd Basement Tectonics International Conference, p.227-240.

Beydoun Z.R., As-Saruri, M., and Baraba, R.S. (1996). Sedimentary basins of the Republic of Yemen: their structural evolution and geological characteristics. Revue Institute Francais Petrole, v. 51, p. 763-775.

Beydoun, Z.R. (1964). The stratigraphy and structure of the eastern Aden Protectorate. Overseas Geology and Mineral Resources Supp. Ser., Bull. Supp. v. 5. HMSO, London.

Beydoun, Z.R. and Greenwood, J.E.G.W. (1968). Aden Protectorate and Dhufar, in Lexique Stratigraphique International. Vol. III., Asie (L. Dubertret, ed.), CNRS, Paris, Fasc. 1062 p.

Beydoun, Z.R., Bamahmaud, M.O., and Nani, A.S.O. (1993). The Qishn Formation, Yemen: lithofacies and hydrocarbon habitat. Marine and Petroleum Geology, v. 10, p. 364-372.

Chang, Y., Song, G., Hsu, S. (1998). Automatic Extraction of Ridge Valley Axes Using the profile Recognition and Polygon-Breaking Algorithm. Computers and geosciences, Vol. 24, No. 1, 83-93.

Csato, I., Habib, A., Kiss, K., Koncz, Zs., Lorinz, K., Milota, K. (2001). New Views of the Subsurface play concepts of oil exploration in Yemen. Oil and Gas Journal, V.99,no.23,PP36-47.

Ellis, A.C., Kerr, H.M., Cornwell, C.P., and Williams, D.O. (1996). A tectonostratigraphic framework for Yemen and its implications for hydrocarbon potential. Petroleum Geoscience, v. 2, p. 29-42.

Guo, G., and H. B. Carroll. (1995). A New Methodology for Oil and Gas Exploration Using Remote Sensing Data and Surface Fracture Analysis. DOE Report No.NIPER/BDM-0163.

Herman, J., P. J. Etzler, M. L. Wilson, and R. K. Vincent. (1986). Remote sensing Study of the Mid-continent Geophysical Anomaly in Iowa. Paper presented at the Society of Mining Engineering Fall Meeting, St. Louis, Missouri, September 7-10, 1986.

Hughs, G.W., and Beydoun, Z.R. (1992). The Red Sea-Gulf of Aden: Biostratigraphy, Lithostratigraphy and Paleoenvironments. Journal of Petroleum Geology, v. 15, p. 135-156. 
Johnsgard, S. K. (1983). The Fracture Pattern of North-Central Kansas and its Relation to Hydrogen Soil Gas Anomalies over the Mid-continent Rift System. Kansas Geological Survey Open-file Report, 88-25.

Lillesand, T.M and Keifer, R.W. (1999). Remote Sensing and Image Interpretation. 4th Edition.

Mah, A., Taylor, G.R., Lennox, P. and Balia, L. (1995). Lineament Analysis of Landsat Thematic Mapper Images, Northern Territory, Australia. Photogrammetric Engineering and Remote Sensing, Vol. 61, No. 6, 761-773.

Nama, E.E. (2004). Lineament Detection on Mount Cameroon During the 1999 Volcanic eruptions Using Landsat ETM. International Journal of Remote Sensing, Vol, 25, No. 3, pp.501-510.

Paul, S.K. (1990). People's Democratic Republic of Yemen: a future oil province. in Brooks, J., ed., Classic Petroleum Provinces. London, Special Publications of the Geological Society, v. 50, p. 329-339.

Powers, R.W., Ramirz, L.F., Redmond, C.D., and Elberg, E.L. (1966). Sedimentary Geology of Saudy Arabia in Geology of the Arabian Peninsula. United States Geological Survey Professional Paper 560-D.

Qari, M.Y.H.T. (1991). Application of Landsat TM Data to Geological Studies, Al-Khabt Area, Southern Arabian. Photogrammetric Engineering and Remote Sensing, Vol. 57, No. 4, 421-429.

Redfern, P., and Jones, J.A. (1995). The interior rifts of the Yemen - analysis of basin structure and stratigraphy in a regional plate tectonic context. Basin Research, v. 7, p. 337-356.

Schlumberger. (1992). Looking for Yemen's hidden treasure. Schlumberger Technical Services Dubai, Middle East Well Eval. Rev., v. 12, p. 12-29.

Suzen, M.L., Topark, V. (1998). Filtering of Satellite Images in Geological Lineament Analysis: An Application to a fault Zone in Central Turkey. International Journal of Remote Sensing, Vol. 19, No. 6, 1101-1114.

Swanson, D. C., and P.J.Shannon. (1990). Landsat Interpretation Useful in Hugoton Gas Field. World Oil, 108-111.

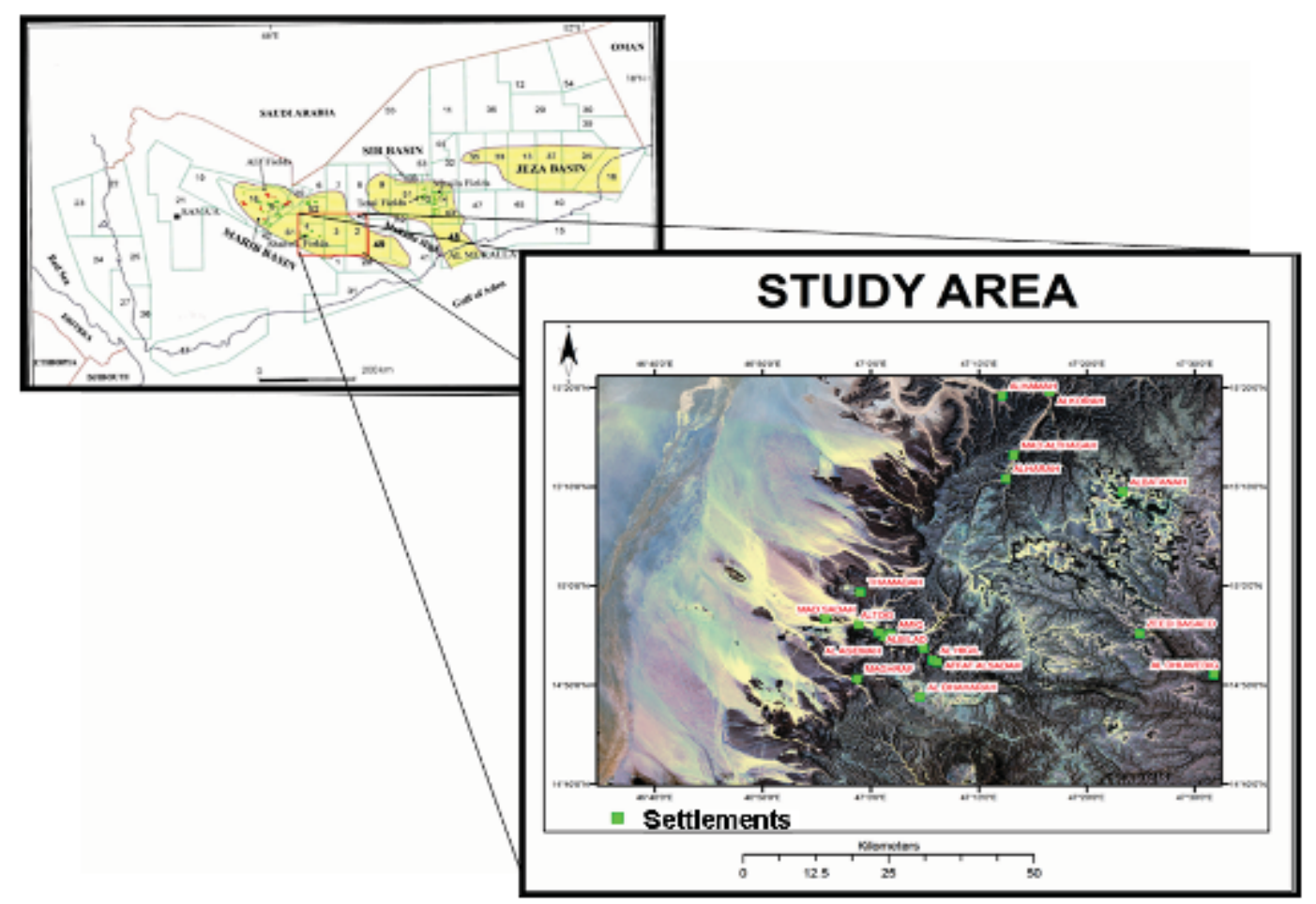

Figure 1. Study area 


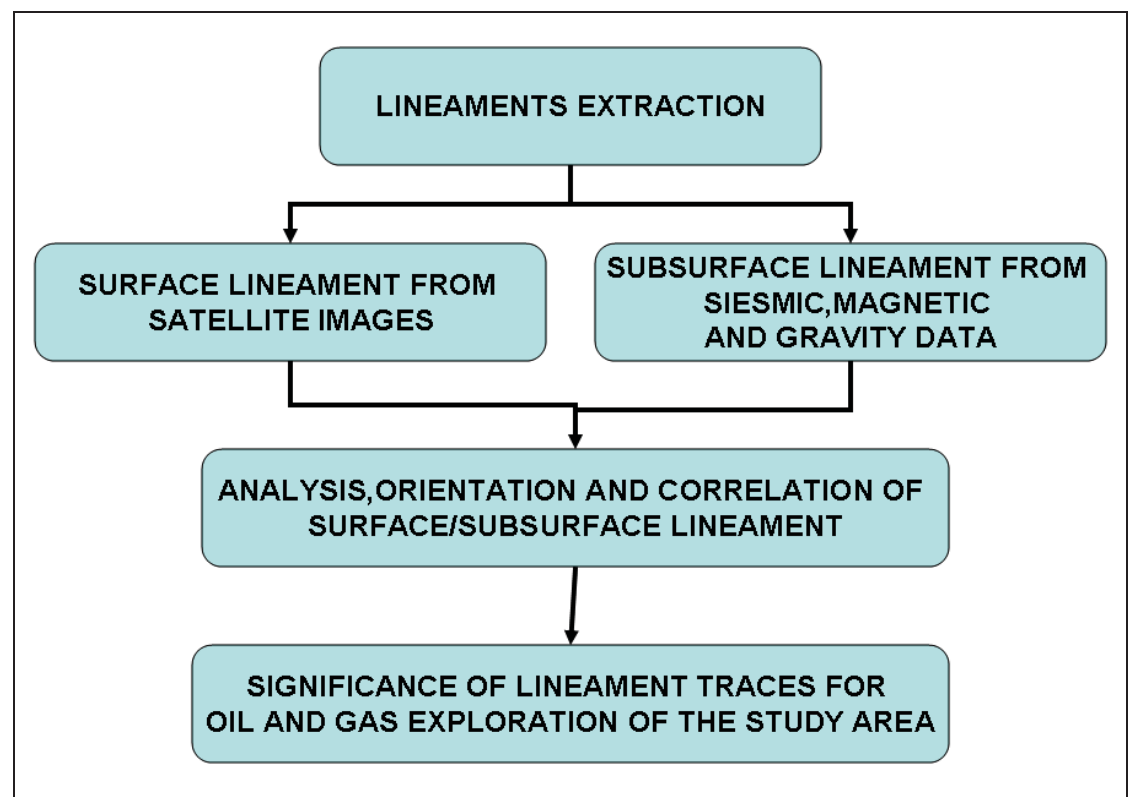

Figure 2. Method of study

\section{SURFACE LINEAMENTS INTERPRETED FROM SATELLITE IMAGERY}

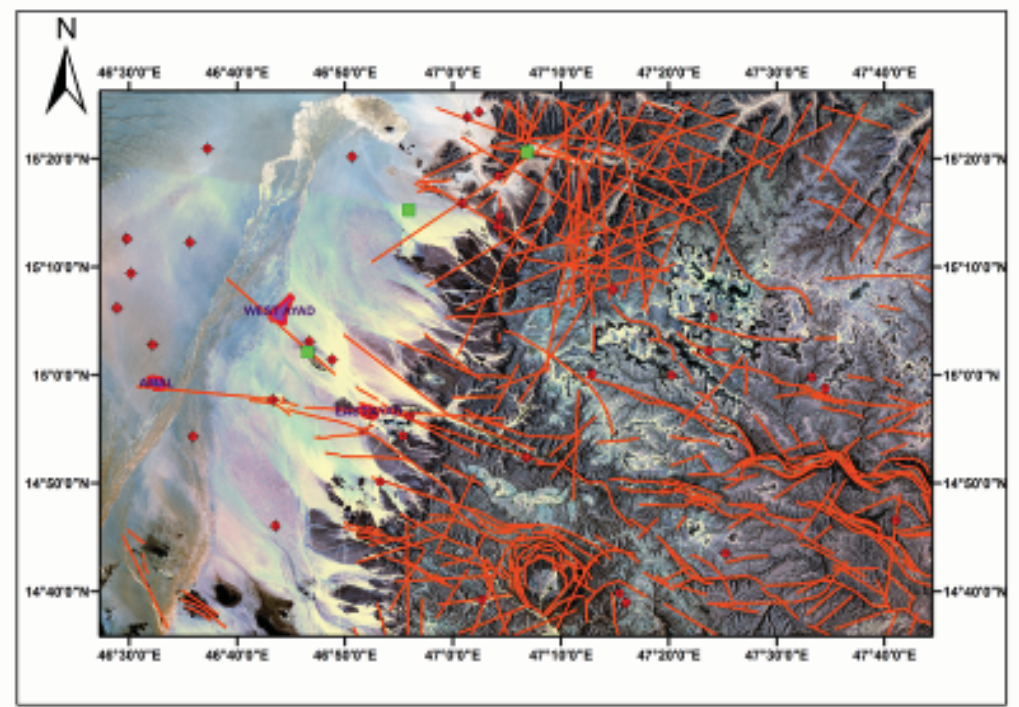

\section{Legend}

Active Oil Seeps

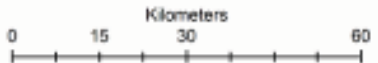

- Wellbores Locations

Oil \& Gas Fields

Surface Lineaments Extracted from Satellite imagery

Figure 3. Integrated Lineament Map superimposed over Landsat satellite image of the study area showing locations of Oil fields, Exploration Wells and oil seeps 


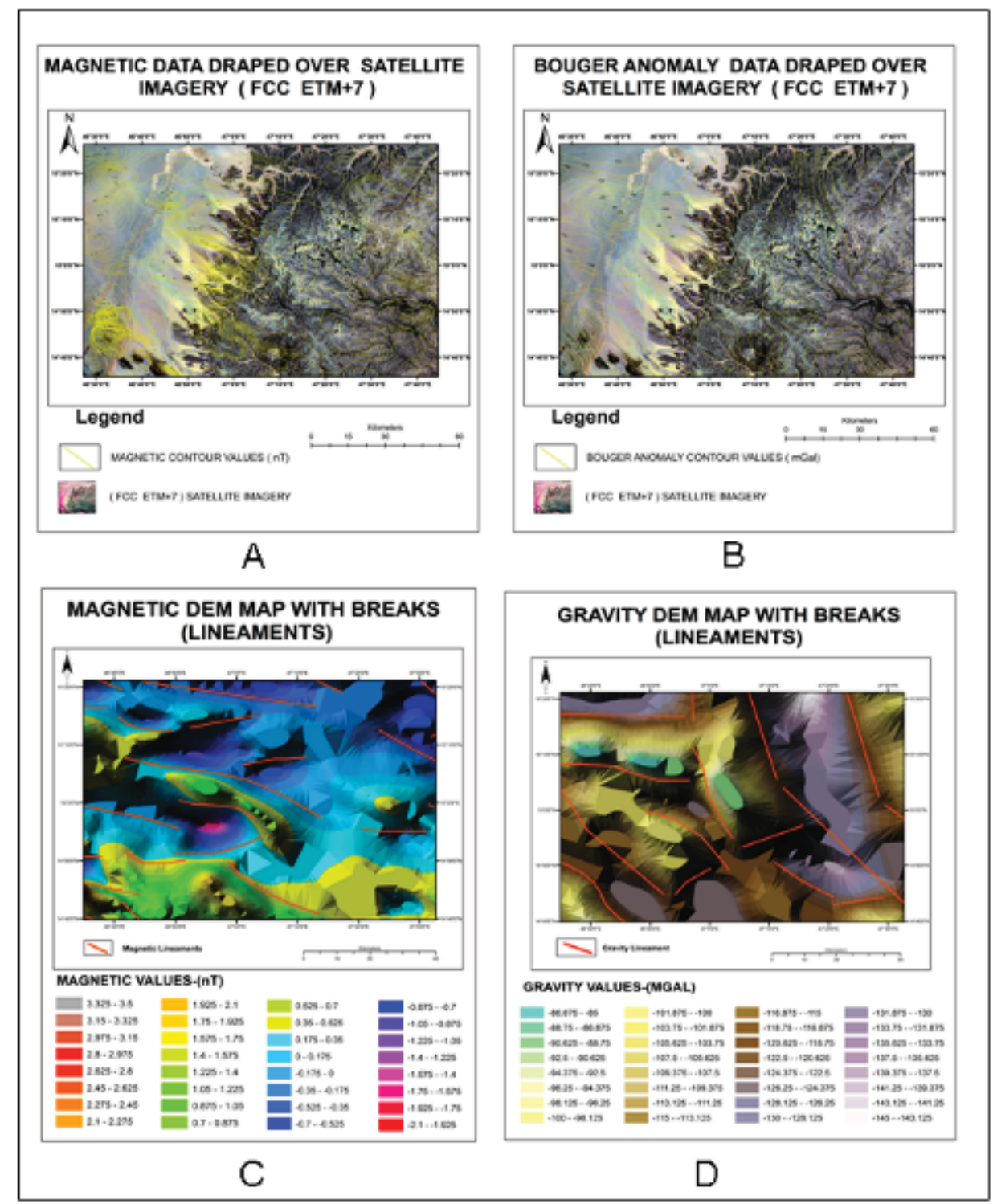

Figure 4. Shows A,B)Magnetic and Gravity contour values superimposed over Landsat satellite image of the study area,C,D)Magnetic and Gravity DEM models 


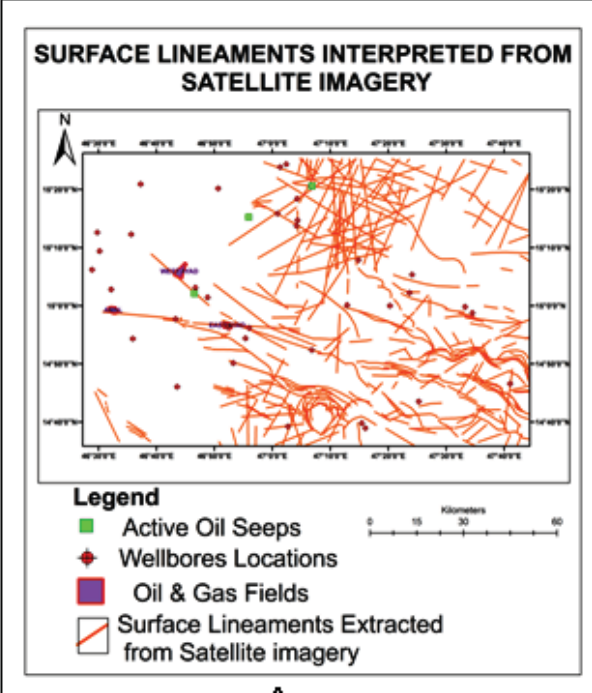

A

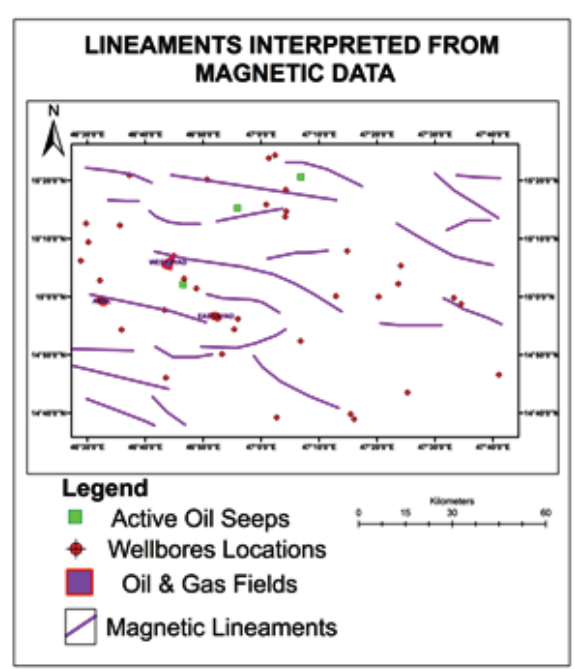

B

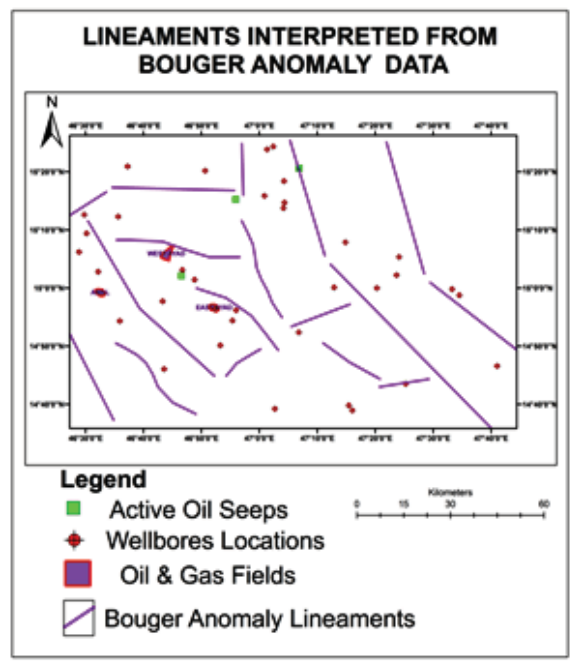

C

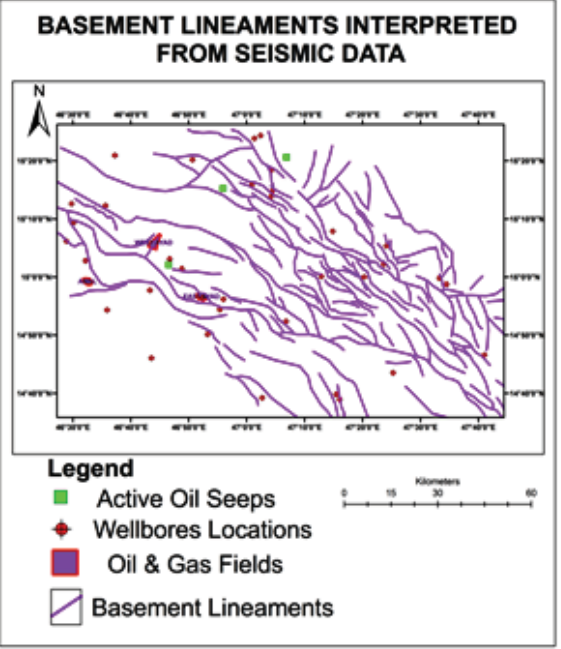

D

Figure 5. Plate showing Surface, Magnetic and Gravity lineaments

And Basement faults of the study area 


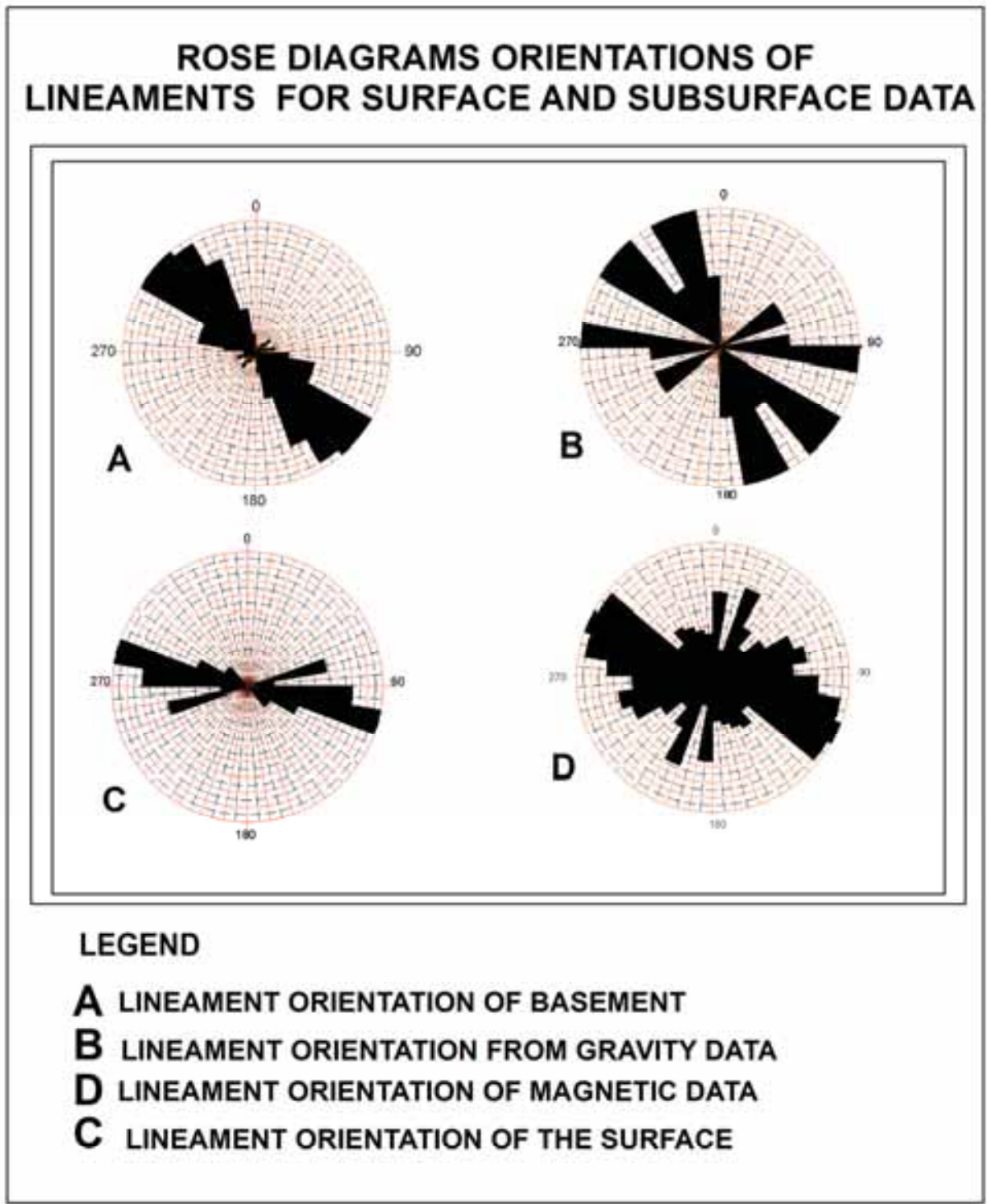

Figure 6. Rose diagrams A, B, C \& D shows orientations of lineaments derived from Basement faults system, gravity, magnetic and surface (satellite) data respectively 


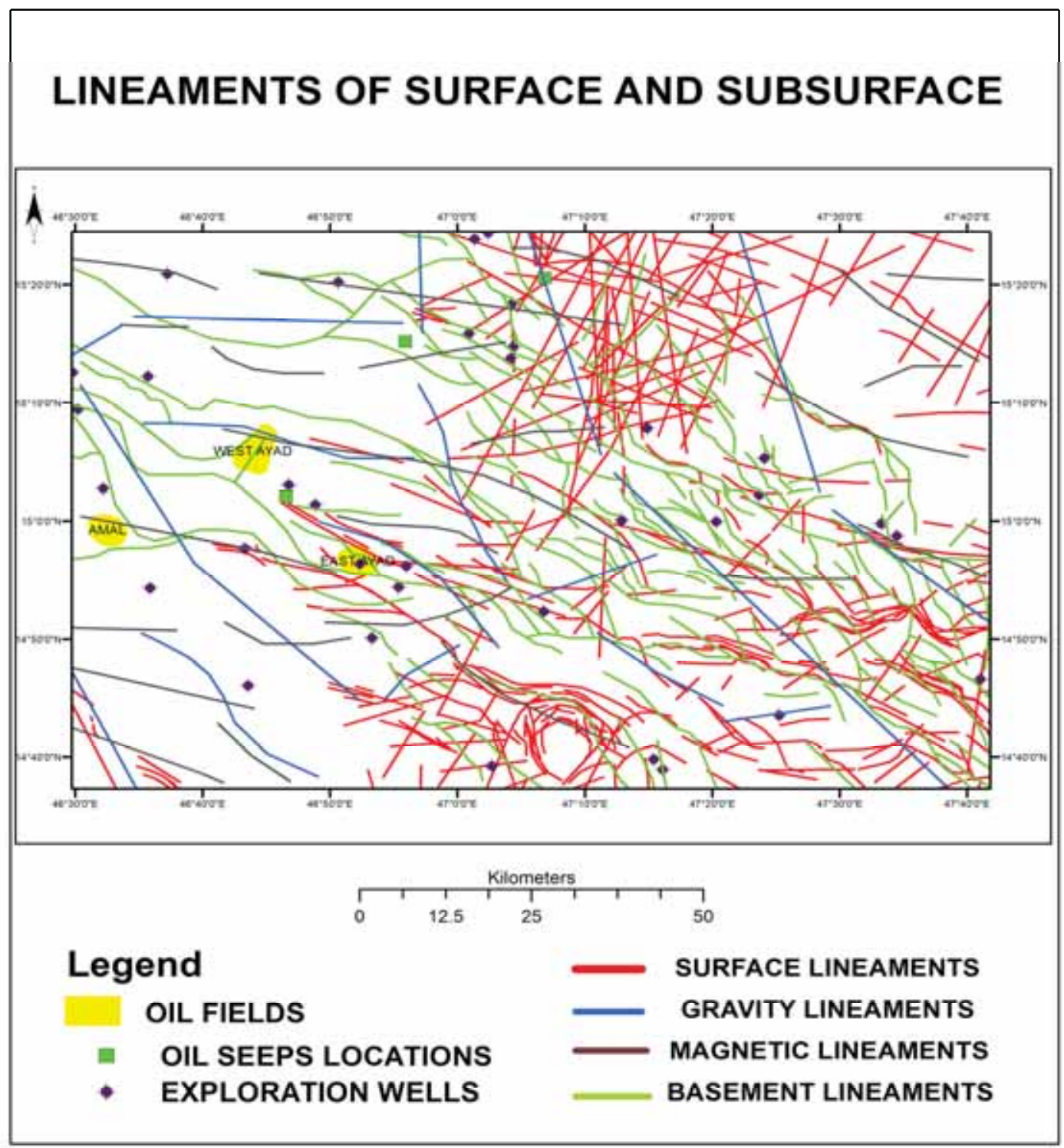

Figure 7. GIS Integrated Lineaments of both surface and subsurface overlaid on oil and gas fields and Active oil seeps in the study area 